https://helda.helsinki.fi

\title{
Language contact in West Africa
}

\section{Lüpke, Friederike}

Routledge

2020

Lüpke , F \& Watson , R 2020 , Language contact in West Africa . in A Evangelia \& Y Matras (eds), The Routledge handbook of language contact. Routledge Handbooks in Linguistics , Routledge, Abingdon, pp. 528-549 .

http://hdl.handle.net/10138/338144

unspecified

acceptedVersion

Downloaded from Helda, University of Helsinki institutional repository.

This is an electronic reprint of the original article.

This reprint may differ from the original in pagination and typographic detail.

Please cite the original version. 
Lüpke, Friederike \& Rachel Watson. Forthcoming. Language contact in West Africa. In: Adamou, Evangelia \& Yaron Matras (eds.): The Routledge handbook of language contact.

\section{LANGUAGE CONTACT IN WEST AFRICA}

Friederike Lüpke (University of Helsinki) and Rachel Watson (SOAS University of London)

\section{Introduction}

Language contact is the impact left by heteroglossic and multilingual language use on a conventionalised language system. Languages are socio-political constructs with varying relations to language use, because of its inherent variation. We conceptualise variation as heteroglossia, here understood as heterogeneity within what is construed as a single language, and as multilingualism, describing language use perceived as involving more than one language. Multilingualism is ubiquitous in (West) Africa, to the extent that it can be considered the unmarked sociocultural condition of communication (Fardon and Furniss, 1994; Gafaranga and Torras, 2016; Lüpke and Chambers, 2010; Myers-Scotton, 1993). Hence, contact is omnipresent and has particularly salient manifestations in explicit contact languages such as the Portugueseand English-based creole languages spoken on its coasts and mixed varieties such as Urban Wolof. Yet, no linguistic setting in this area is exempt from the influences of longstanding mobility, intermingling, trade networks and colonisation. How these factors have shaped languages and language use in this particular geographical area is the focus of this chapter.

The geographical term West Africa is employed as a term of mere convenience, loosely interpreted as corresponding to the Western African portions of long-observed fragmentation and convergence areas (see section 2). This area spans the Sahel region in the north and is delimited by the Atlantic Ocean in its west and south. There are no externally motivated clear-cut territorial boundaries other than the borders of colonially created nation states. Within the region and beyond it, several meaningful socio-political spaces have existed through history (for a discussion of the Mande and Atlantic spaces, see Lüpke, forthcoming b), often coinciding with empires, states and larger polities. None of these had clear demarcations, but all tapered out and overlapped with the peripheries of other powers (Canós-Donnay, 2019). The area hosts great linguistic diversity, with hundreds of local and regional languages co-existing with languages of European provenance serving today as the official languages of West African states which have been appropriated in various ways by its inhabitants. Urban multilingualism and language contact originating in the (pre)colonial trade posts and in modern postcolonial cities is relatively wellstudied (Auzeanneau, Bento and Leclère, 2016; Barry, 1990; Biagui, Nunez and Quint, forthcoming (2019); Calvet, 1993; Cruise O'Brien, 1998; Dreyfus and Juillard, 2004; Intumbo, Inverno and Holm, 2013; Jacobs, 2010; Juillard, 1995; Mc Laughlin, 2001, 2008; Ndecky, 2011; Nunez, 2015; Swigart, 1994); much less known is the widespread rural multilingualism in the 
Lüpke, Friederike \& Rachel Watson. Forthcoming. Language contact in West Africa. In: Adamou, Evangelia \& Yaron Matras (eds.): The Routledge handbook of language contact.

region (Lüpke, forthcoming b; Lüpke and Chambers, 2010) and in Africa as a whole (Di Carlo, 2018; Good, Di Carlo and Ojong, 2019), and the interaction between rural and urban sites, resulting in different but connected planes of language use. Sites and their connections, historical developments, language ideologies and territorialisation models and linguistic identity formations are surveyed in 2 .

Section 3 addresses critical issues arising from the study of multilingualism and language contact in a geographical area in which standardised language varieties play only a minor, mainly symbolic, role in communication and in which language history remains largely unknown. Standard languages commonly serve as the reference points to measure multilingualism (in terms of repertoires captured in terms of named languages) and to describe multilingual speech through allowing the identification of contributing codes. Where standard languages are not much used in linguistic interaction, as is the case in many West African settings (Canut, 2010; Donaldson, 2018; Lüpke, forthcoming c), language use is fluid in many contexts and thus defies easy categorisation.

Because of the concentration of much historical linguistic research on genealogical relatedness, to the exclusion of language contact, the diachronic development of West African languages is an area of great debate. The morpho-phonological characteristics of many West African languages, in particular Atlantic languages, many of which feature stem-initial consonant mutation, make the historical method inapplicable (Pozdniakov, 2007). Additionally, monoparental models of relatedness such as the genealogical model can only account for a limited proportion of language change in an area where speakers of closely related languages remain multilingual and/or intermingle continuously over long time spans. It is often impossible to distinguish features inherited from an ancestor from features diffused through language contact, in particular because features arising from diffusion are also passed down genealogically once established (François, 2017) and vice versa. Genealogical groupings beyond the level of family remain contested (Childs, forthcoming (2019); Dimmendaal and Storch, 2016; Pozdniakov and Segerer, forthcoming (2019)). Newer network methods modelling both vertical and horizontal relatedness have been used (Pozdniakov and Segerer, 2010), but not found reflections in publications yet.

Despite the availability of languages of wider communication for at least the last millennium, linguistic diversity has been upheld in West Africa. Language evolution and change must therefore be conceptualised along the axes of convergence and divergence. Convergence results in contact languages and in contact features touching all areas of language, while divergence is manifest in the maintenance of separate languages and of small emblematic differences. While convergences testify to the homogenising forces of language processing demands and of communicative needs, divergences counteract them because they enregister features that express 
Lüpke, Friederike \& Rachel Watson. Forthcoming. Language contact in West Africa. In: Adamou, Evangelia \& Yaron Matras (eds.): The Routledge handbook of language contact.

socially meaningful facets of identity (Silverstein, 2003; Agha, 2005; Eckert, 2008). We therefore present a new epistemological focus in section 4 that moves interactional features and socialindexical motivations to centre stage (Matras, 2009, 2012). Such recentring recognises that language use (which we also call languaging, see Wei, 2018 for a history of the term and of the related notion of translanguaging) is dynamic and variable while at the same time containing a solid core that is reified in the mind of users and analysts. The social and cognitive motivations underlying this reification that operate according to different parameters from standardisation, and the features indexing social difference, move to centre stage in this approach. The framework we suggest relies on examining language use and metalinguistic judgements to determine the prototypicality of different features in both individual and collective conceptualisations of language. We formalise these different viewpoints on linguistic matter by introducing the notions of scale and perspective (Gal, 2016; Irvine, 2016), and discuss how the perspectives of different actors - speakers/signers/writers, hearers/readers and analysts - can contrast or coalesce.

In section 5, we address methodological advances in the study of West African language contact, focussing on the combination of multiple perspectives through working in multidisciplinary teams, complementing corpus-based research with sociolinguistic methods and linguistic anthropology, the adoption of genre-differentiated analyses and the inclusion of the spoken, signed, and written modality, which all constitute promising avenues for future research.

\section{Historical overview}

\subsection{West Africa as an area of linguistic fragmentation and diffusion}

The simultaneous existence of a high number of small languages and of far-reaching multilingualism and intense language contact can be captured in the area being classified as a zone of fragmentation and spread at the same time. On the one hand, West Africa is part of the "Sub-Saharan fragmentation belt" (Dalby, 1970), a zone of great linguistic diversity, and on the other hand it is characterised by significant yet uneven spreads of linguistic features formalised in the Macro-Sudan belt (Güldemann, 2008; Güldemann, 2010; Güldemann and Hammarström, forthcoming). The Macro-Sudan belt is based on the (partial) presence of logophoric pronouns, labiovelar consonants and labial flaps, ATRbased vowel harmony, and the word orders S-(AUX)-O-V-X and V-O-NEG. Phonological features single out a largely overlapping spread zone called the Sudanic belt, based on the common occurrence of labial flaps, labial-velar stops, implosives, phonemic nasal vowels, ATR-based vowel harmony, complex tone systems and "lax" prosodic marking of questions (Clements and Rialland, 2008). These divergence and convergence areas span grass and tree savannah and dry forests, with some areas of rain forest on the coastal and southern fringes. While north-south spread of features is attested and mainly associated with long-distance trade, the major direction of feature spread is latitudinal, as are 
Lüpke, Friederike \& Rachel Watson. Forthcoming. Language contact in West Africa. In: Adamou, Evangelia \& Yaron Matras (eds.): The Routledge handbook of language contact.

most migratory movements, in line with the universal observation that features have a greater potential to spread laterally and are more constrained in their longitudinal diffusion (Diamond, 1999; Güldemann and Hammarström, forthcoming). Similar climatic and ecological environments aligned along latitudinal bands facilitate migration, cohabitation and exchange, and hence language contact is produced by social interaction in particular environments (Bentz et al., 2018; Mufwene, 2001).

\subsection{Different West African language ecologies}

Since particular environmental and social factors give rise to site-specific patterns of multilingualism and language contact, these settings are becoming a focus of research in their own right. This endeavour is particularly relevant in the light of the call for globalising sociolinguistics (Childs, Good and Mitchell, 2014; Smakman and Heinrich, 2015; Di Carlo, Agwara and Ojong, forthcoming) and language documentation and description (Di Carlo, 2016; Di Carlo and Good, 2017; Lüpke, 2017; Mufwene, 2017) so as to shed light on the small-scale societies in which most of language contact takes place (Trudgill, 2011; Lüpke, 2016b). Understanding how verifiable migration and settlement patterns, social exchange and mobility shape language practice and language ideologies is an indispensable prerequisite for the interpretation of divergence and convergence patterns with greater time-depths and larger geographical distribution, for which no detailed historical knowledge and no linguistic records are available.

Throughout West Africa, small-scale rural language ecologies in Frontier societies (Kopytoff, 1987), widespread at the fringes of larger states, are noteworthy in this regard. In these societies, small family-based groups (often patriclans) have moved and settled over long periods of time, regrouping and intermingling with near-by clans and constantly engaged in social exchanges including intermarriage. At the same time, they maintain(ed) discrete social identities that can also be indexed by language and allow the forging of maximal, yet flexible, alliances. These ecologies are characterised by very high levels of multilingualism, with 3 to 10 languages comprising typical individual repertoires, whose named languages in turn comprise multiple lects. Only very few of these small-scale ecologies have been studied in depth. Among the case studies are a number of geographically close, but sociolinguistically distinct settings in the Lower Casamance in Southern Senegal (Cobbinah, 2010; Lüpke, 2010; Cobbinah et al., 2016; Goodchild, 2016; Goodchild and Weidl, 2018; Watson, 2018; Weidl, 2019; Goodchild 2019; forthcoming (2019); Cobbinah, forthcoming), and the Lower Fungom area in Northwestern Cameroon (Good, 2013; Di Carlo and Good, 2014; Di Carlo, Agwara and Ojong, forthcoming). All these areas are characterised by topographical features that favour the existence of small, village and ward-based groups, such as marshlands and river deltas (in the Casamance case) or mountainous terrain (in Cameroon).

In larger polities, less linguistic heterogeneity is built into social organisation, since endogamous marriage and polity-internal exchange becomes more widespread. One such polity in the Lower 
Lüpke, Friederike \& Rachel Watson. Forthcoming. Language contact in West Africa. In: Adamou, Evangelia \& Yaron Matras (eds.): The Routledge handbook of language contact.

Casamance, where its location on a peninsula has resulted in one of the larger political formations in the region, the small kingdom of Mof Avvi, has been described in detail (Goodchild, 2019; forthcoming (2019); Sagna, forthcoming (2019)). Larger socio-political spaces often associated with state formations (and situated in regions that climatically and geographically facilitate easy movement of larger groups and armies, such as the West African savannah) also exhibit linguistic diversity on a smaller scale, as discussed for the contrasting Atlantic and Mande spaces of West Africa (Lüpke, forthcoming b; Lüpke et al., under revision (2019)).

Yet, all these settings were or are linked to larger exchange patterns through seasonal or permanent migration, pilgrimage, trade and external and internal slavery. The focal points of much, though not all, migration, has been to urban centres. Precolonial cities have existed throughout the known history of the area (Coquery-Vidrovitch, 2005). For some, we have evidence for the patterns of multilingualism practiced in them through the written language contact exhibited in manuscripts in the Arabic script produced in urban centres of scholarship such as Djenné, Timbuktu, and many others (Ngom, 2017). The co-existence of Arabic-script writing in Arabic and in languages other than Arabic (so-called Ajami writing) in these manuscripts is subject of a growing body of research (Tamari and Bondarev, 2013). Other urban centres originated as trading and slaving posts of Iberian and later other European settlers on the West African coast. In the wake of their foundation and the formation of a broker class of intermediaries, intermarrying with the settlers and participating in the slave trade, a Portuguese lexifier Creole (Kriolu) emerged on the Cape Verde archipelago from where it was transported to the Upper Guinea Coast mainland in the $16^{\text {th }}$ century (Jacobs, 2010), where it now has become the major lingua franca of Guinea Bissau and an important vernacular and vehicular language of the adjacent Casamance region of Senegal (Biagui, Nunez and Quint, forthcoming (2019); Intumbo, Inverno and Holm, 2013). Other, English-lexified, contact languages are Nigerian Pidgin English (Faraclas, 2013) or Naija and Krio or Aku, spoken in Sierra Leone (Finney, 2013). A number of originally urban varieties such as "Urban Wolof" in Senegal which are sometimes described as creoles (Swigart, 1994) can also be attributed to the existence of local intermediaries between colonists and indigenous populations. Their speech exhibited many lexical influences from French or English which now have become a widespread and unmarked way of speaking in many settings (cf. Nouchi in Côte d'Ivoire (Boutin and N'Guessan, 2015), Camfranglais in Cameroon (Chia, 1990; Kießling, 2005, etc.). The excolonial European languages of West Africa are distinct from their metropolitan varieties and exhibit great fluidity (Manessy, 1994; Chaudenson and Calvet, 2001; Gut, 2015). Many speakers are multilingual in the mixed registers and their component codes, which are all highly heteroglossic, giving rise to forms that can be seen as monolingual, code-switched, fused or ambivalent, depending on perspective. Rural and urban settings were always connected, but rapidly increasing urbanisation and the availability of new media to facilitate oral and performative written communication over large distances intensify and transform multilingualism patterns, and their 
Lüpke, Friederike \& Rachel Watson. Forthcoming. Language contact in West Africa. In: Adamou, Evangelia \& Yaron Matras (eds.): The Routledge handbook of language contact.

influences on language contact remain to be researched in more detail (Lexander, 2010; Mc Laughlin, 2014; Lexander and Alcón, forthcoming (2019).

\section{Critical issues and topics}

\subsection{West African ideas of language and of language territorialisation}

Strong ideological connections between language(s) and place exist in West Africa. However, contrary to the European model of the ethnic nation state, with language as the central marker of ethnicity (Fishman, 1989), most West African settlements are not based on the idea of an ideally homogeneous language community.

Widespread firstcomer-latecomer or landlord-stranger settlement patterns (Brooks, 1993; Lentz, 2013) accord a special status to the founders of a place and their (mostly male) descendants, and it is the founder's or ruler's language that becomes associated with the place, a deictic value that is likely mirrored in the Founder principle formulated for creole studies (Mufwene, 1996) that ascribes farreaching influences on its linguistic organisation to the founders of a settlement. Founder languages have been called patrimonial languages by Lüpke (2018) to draw attention to the fact that these languages only correspond to a fraction of the linguistic repertoire of the inhabitants of a place; that they are not expected to be shared by all of them, and the contexts in which they are exclusively used are often limited to particular ceremonial contexts related to ancestors, land and land rights - the patrimony. Such an imagination of language contrasts with an ancestral territorialisation model (Blommaert, 2010; Woodbury, 2005), more akin to the language ideologies of the nation state, in which only one language has a right of residence, and linguistic assimilation of all who are deviant from it is desired. Ancestral language ideologies are linked to a categorical view of linguistic identity, where one and only one language occupies a special position in a given space and is deemed to express its inhabitants' identity in an absolute fashion.

Ethnicity is a concept introduced to (West) Africa in colonial times (Ranger, 1983; Amselle and M'Bokolo, 1985; Amselle, 1990; Lentz, 1995;). Ethnic labels, encapsulating outsiders' views, are applied over internally heterogeneous linguistic spaces in which local differences signal important local identities. Ethnic identities have gained social reality in contemporary societies, but without yet finding a direct linguistic equivalent. However, ethnic affinity among speakers of related languages invites the categorisation of these languages, which can be named based on more locally confined features, as being instantiations of one superordinate ethnic language at a larger scale and may over time result in convergence (see Bazin, 1985 for a Malian example and Lüpke, 2016a for a case study in Senegal).

Relational, rather than categorical, identities are widespread in West African contexts (Good, Di Carlo and Ojong, 2019). Both in terms of ethnicity and in terms of language use, they enable an individual to claim and perform multiple and variable identities dependent on their trajectories, repertoires and 
Lüpke, Friederike \& Rachel Watson. Forthcoming. Language contact in West Africa. In: Adamou, Evangelia \& Yaron Matras (eds.): The Routledge handbook of language contact.

situational needs. It is difficult to formalise West Africans' adaptive repertoires, especially since categories such as mother tongue, first and second language, even when assumed as plural categories, in many cases do not capture language acquisition and socialisation (Cissé, forthcoming (2019)) of the region's mobile inhabitants (see the snapshots of GS's repertoire in figure 2 and 3 for an illustration). Patrimonial languages are often mistaken to correspond to mother tongues or L1s, but their function is to link individuals to ancestral places of origin where they have land rights according to historically anchored mobility patterns (Brooks, 1993; Lentz, 2013), and individuals may not speak them at all. In particular, we find that a triglossic picture, with excolonial and now official languages at the top, languages of wider communication in the middle, and locally confined languages at the bottom of a hierarchically organised pyramid, does not fully explain situated and relational language use patterns. We consider the terms 'vehicular' and 'vernacular' useful, in addition to the notions of patrimonial language, not to categorically delimit a language's role in a society, but to discuss the different and changeable roles and differential affective values of named languages in an individual's repertoire. The role of a language is multidimensional, dependent on factors such as patrimonial, other ancestral and relational identity links, frequency of use, attitudes, and access to conventionalised norms, such that the same named language may play quite a different role in different people's repertoires; moreover that role is dynamic and may change over time and even in different situations. Repertoire studies make use of language portraits (Busch, 2006) and other, individual-specific profiles resulting from in-depth ethnographic fieldwork. While these allow gauging the complexity of repertoires and the speaker-individual circumstances shaping them, they do not lend themselves to generalisations or comparisons. Therefore, we here suggest a frame built on the factors mentioned above that contribute to the role that a language plays in an individual's repertoire.

We visualise these factors as contributing to a cumulative whole which represents the role of the language in an individual's repertoire at a given point in time. The relative value of each factor is represented by the size of the corresponding section in the bar; the relative size of the entire bar indicates whether the language plays a more vernacular (longer bar) or vehicular (shorter bar) role in the repertoire of the individual. The visualisations underscore the fact that the different factors are not necessarily congruent. A language may have a high value for, say, patrimonial identity, but not for frequency of use or access to conventionalised norms. The values can be adjusted - both increased and decreased - over an individual's lifetime, or even in different spatial or situational contexts. Figures 1 and 2 below illustrate how these functions can cluster differently at different times (in 1995 and in 2015) in the life of GS, a man in his 30ies from Casamance, Senegal. The scores are based on ethnographic research and sociolinguistic interviews, and are assigned on a heuristic and relational, rather than an absolute, basis. 
Lüpke, Friederike \& Rachel Watson. Forthcoming. Language contact in West Africa. In: Adamou, Evangelia \& Yaron Matras (eds.): The Routledge handbook of language contact.

A more complete vignette on GS can be found in Lüpke et al. (under revision (2019)). In 1995, he was living in Essyl, a village whose patrimonial language is Joola Banjal. The patrimonial language of GS' father's village is Baïnounk Gubëeher, which he only learned when he moved to live with his father in Djibonker. Wolof is the de facto national language of Senegal, while French is its official language. Bayot is a macro-language associated with Niassia, the village where he spent his early childhood.

Figure 1: Roles of named languages in GS's repertoires in 1995

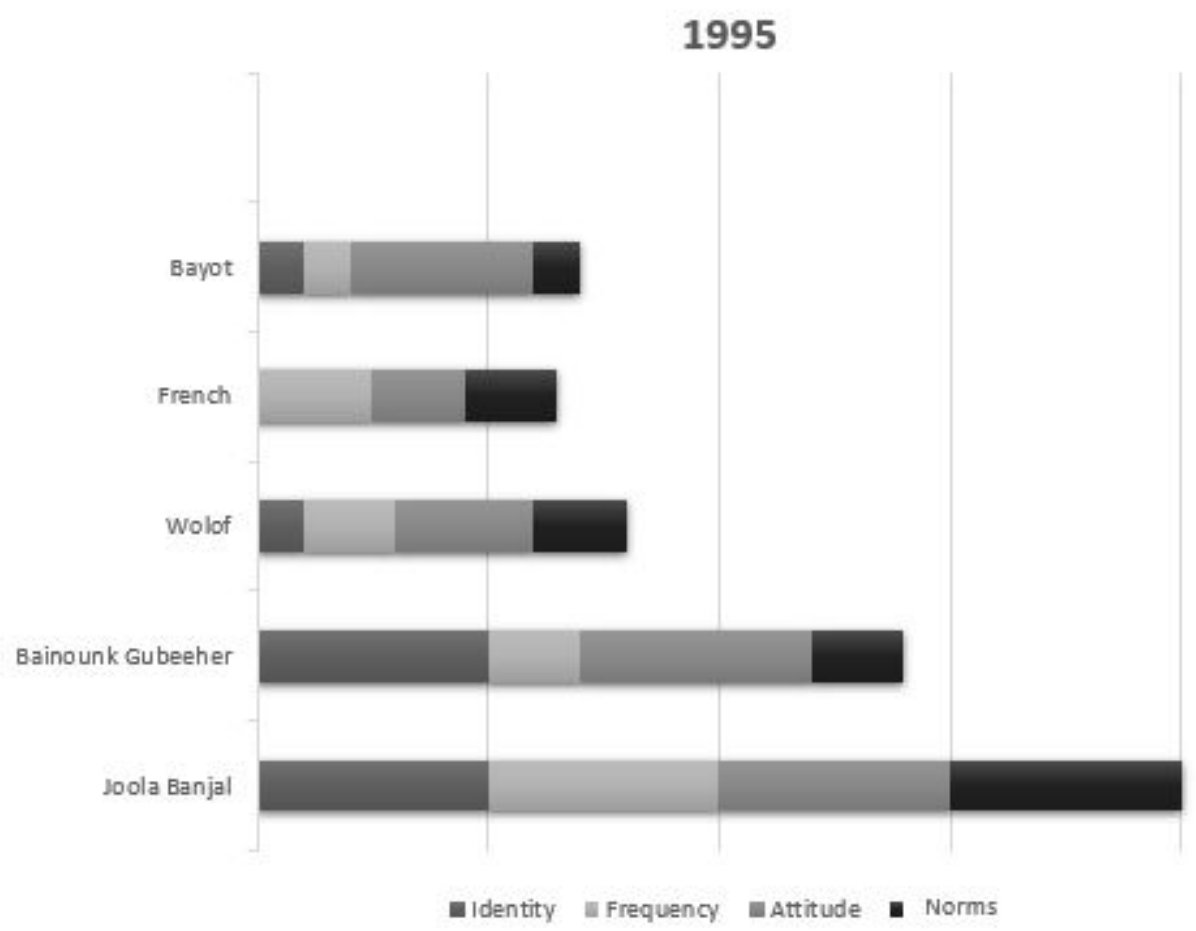


Lüpke, Friederike \& Rachel Watson. Forthcoming. Language contact in West Africa. In: Adamou, Evangelia \& Yaron Matras (eds.): The Routledge handbook of language contact.

Figure 2: Roles of named languages in GS's repertoires in 2015

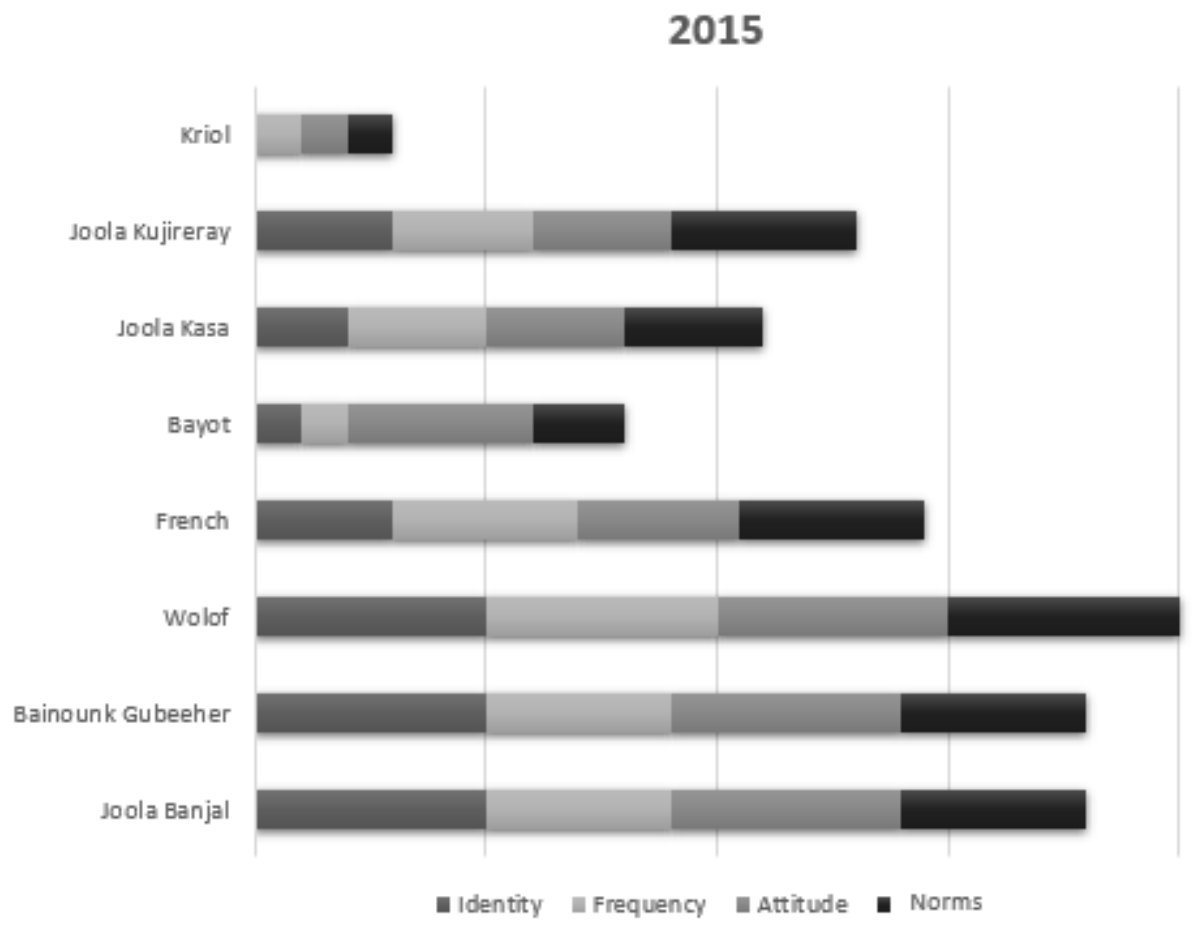

Three languages have been added by 2015 , at which time GS lives in his father's village Djibonker and has had occasion to learn and speak its patrimonial language Baïnounk Gubëeher. The village next door is associated with Joola Kujireray, closely related to Joola Banjal, which he has also learned. Additionally, he has picked up Kriolu by interacting with palm wine tappers from neighbouring Guinea Bissau. The snapshots on these figures are intended to serve as a heuristic representation only, to complement and not to replace detailed descriptions of repertoires (Goodchild, 2019; Weidl, 2019). They illustrate the great size (both in terms of un- and remotely related languages and closely related lects) and the enormous variability and adaptability of repertoires, induced by small-scale mobility (the two places of residence are ca. 10km apart from each other) and changing social networks throughout an individual's life. Further research is required to refine and formalise such visualisations, which would ideally include information on adherence to linguistic norms and frequency mined from corpus data - although see Section 4.1 below for discussion of obstacles to be overcome in this respect.

\subsection{Emblemacity, scale and perspective}

Languages are bound to exhibit similarities at a structural level, through close genetic inheritance and/or intense and ongoing contact. They can also converge through indexing overarching 'macroidentities' such as those created by the introduction of ethnic categories. In the case of closely related languages, small differences become significant in distinguishing differential social meaning. Social 
Lüpke, Friederike \& Rachel Watson. Forthcoming. Language contact in West Africa. In: Adamou, Evangelia \& Yaron Matras (eds.): The Routledge handbook of language contact.

identities are multifaceted, and considerations of scale and perspective come into play as different identities crosscut or nest within each other. These factors lead to a structurally and socially multilayered contact situation, which results in complex patterns of convergence and divergence.

Even a single utterance can contain social meanings on different levels. This is illustrated concisely in formulaic greetings in Joola (see also Hantgan, 2017; Lüpke et al., under revision (2019). The Joola languages belong to the Bak branch of Atlantic, spoken from the Gambia to Guinea Bissau. Their genetic relatedness is relatively uncontroversial, although internal classification is confounded by long and extended contact. In Joola languages, greetings include the formulaic couplet translatable as '[Is there] peace?', 'Peace, only'. Such a formula is widespread, though not ubiquitous, in the region. Many other languages use equivalent, although not phonologically related, expressions in their greetings, which can be regarded as instances of pattern convergence. Table 1 shows the typical response form - 'peace only' according to a broad sub-regional distribution. The form KASUMAY keb is associated with Joola Fogny, the dominant Joola variety and thus has rather universal usage throughout Casamance. KASUMAY is shown in caps to indicate that this is a schematic representation of a form that has many different phonetic realisations across the region (see below for discussion).

Table 1 Joola greetings: 'peace only'

\begin{tabular}{|l|l|}
\hline Form: 'peace only' & Region \\
\hline KASUMAY keb & North of Casamance river (most widespread) \\
\hline KASUMAY bare & South of Casamance river \\
\hline KASUMAY lamba & North-western part of Casamance \\
\hline
\end{tabular}

The convergent part of the formula facilitates communication, as the form is universally understood throughout the region. It also allows the indexation of a broad, pan-Joola identity. The second part, 'only', also allows social indexation on a more fine-grained level, showing a connection with a particular sub-region. Zooming in even further, we also find levels of distinction maintained within these sub-areas, which can be indexed through differences in pronunciation of KASUMAY. For example, it has been shown that a contrast in word initial $[\mathrm{g}]$ and $[\mathrm{k}]$, and other small differences in pronunciation in the form $K A S U M A Y$, can be used to index differential linguistic identities at the village level even when the pan-Joola (i.e. KASUMAY), and sub-regional (i.e. 'only') identity indexed are identical (Sapir, 1975; Hantgan, 2017; Watson, 2019). Some features may take on special indexical power and become emblematic of a particular identity. A form can be emblematic at different levels of specificity, with an inverse relation between the reach of a form and the specificity of the identity it can index. The indexical power of a linguistic feature is also subject to effects of 
Lüpke, Friederike \& Rachel Watson. Forthcoming. Language contact in West Africa. In: Adamou, Evangelia \& Yaron Matras (eds.): The Routledge handbook of language contact.

perspective, as it is dependent on contrast. It is only a feature that is salient from a number of different viewpoints that has the potential to be emblematic.

The following section discusses the issues of scale, perspective and emblematicity through identifying convergent and divergent features in a text that can be differently categorised as heteroglossic and/or multilingual.

\section{Current contributions and research}

\subsection{Rethinking reification}

Reification of language is a universal practice driven by the human propensity to categorise. Languages may be reified in different, sometimes conflicting ways by actors, according to contrasting perspectives and motivations. Speakers of languages reify them to facilitate social-indexical requirements, reinforcing identity and group membership, facilitating maintenance of many small languages, and perpetuating prescriptive ideals and myths of 'correctness'. Descriptive linguists reify languages in word lists and grammars in a process of artefactualisation which may also carry ideological baggage prioritising monolingual language situations, standardisation and nostalgic notions of an ancestral code. Reifications result in erasure of variation, and often background multilingualism, obscuring facts that may allow us to investigate language contact. In addition, effects of scale and perspective can mean that numerous reifications may exist that are seemingly contradictory. It is increasingly recognised that descriptive linguists must find a more dynamic way to describe languages that can take into account variation, multilingualism and different levels of scale and perspective (Childs, Good and Mitchell, 2014; Marten and Petzell, 2016; Watson, 2019; Lüpke, forthcoming $b$ ), with reifications treated as cognitive phenomena rather than empirical facts.

Nevertheless, some form of description is a prerequisite if we wish to analyse multilingual discourse, mine multilingual corpora and examine contact effects. At present such analysis is hampered by the fact that it can be impossible to identify the languages involved in such data in a principled way, particularly, but not only, if the languages are closely related. If languages are un- or underdescribed, spoken by highly multilingual speakers in dynamic contact situations, we have no way of knowing which features come from where. Speakers' categorisations are often based on non-linguistic features such as the known identity of discourse participants or the setting, in addition to the shape of their repertoires. Dependence on descriptions which present a single reification of a language can mean that we risk misinterpreting the data; for example, mistaking heteroglossia or borrowing for codeswitching. Watson (2019) proposes conceptualising, and thus describing, languages based on principles of prototype theory (Rosch, 1975; Rosch and Mervis, 1975) in order to accommodate and account for variation, and to provide flexible, multiperspectival, reference points for the analysis of multilingual discourse and corpora. A language can be modelled as a collection of features that are more or less prototypical of that language, and prototypicality is determined empirically from a wide 
Lüpke, Friederike \& Rachel Watson. Forthcoming. Language contact in West Africa. In: Adamou, Evangelia \& Yaron Matras (eds.): The Routledge handbook of language contact.

variety of data from different speakers, according to factors including consensus, frequency and stability. Languages can then be compared to each other to identify commonalities, with salient differences thus foregrounding the relationships between languages in contact and to allow an examination of contact effects from a fine-grained, diachronic perspective, as well as providing a more reliable foundation for historical studies. The model is compatible with sociolinguistic and lexico-grammatical views of language as collections of features associated with sociocultural constructions that are named languages (Mufwene, 2001; Cheshire et al., 2011; Jørgensen et al., 2011; Blommaert and Rampton, 2012; François, 2014). It is commensurate with work on social networks (Milroy, 1980) which predicts that a stable core is maintained by central conservative speakers, with innovations introduced by social outliers also described for West African settings (Beyer, 2010; Beyer and Schreiber, 2013).

Describing languages in this way requires a systematic methodology based on a holistic research paradigm combining methods from theoretical linguistics and sociolinguistics in novel and properly defined ways. A linguistic description constitutes a model that necessarily must be built empirically, based on large volumes of linguistic data from numerous different speakers, genres and contexts, correlated with rich sociolinguistic data on all speakers and contexts. Tolerance for variation means the only condition on the data used to create this model is that it is a speaker's ascertainable pragmatic intention to speak the language in question. The creation of a prototypicality model therefore begins with elicitation and staged communicative events, since in more naturalistic data it is often not possible to ascertain which language a speaker intends to speak. In addition, token frequency even for high-frequent lexeme types in highly multilingual corpora is not sufficient to systematically establish variational ranges.

The prototypical form of any given feature (from phonetic to syntactic) can be found through examination and aggregation of numerous exemplars from this data, which are extracted and collated in a data base, which also gives us detailed information about the utterance. This is illustrated in table 2 below for the form for 'water' as discussed above (the table is illustrative only - in practice, many more tokens would be required for a reliable description).

Table 2 Forms for 'water' in Joola Kujireray

\begin{tabular}{|l|l|l|l|l|}
\hline $\begin{array}{l}\text { Token } \\
\text { No. }\end{array}$ & Form & Speaker & Context & Interlocutors \\
\hline 1 & {$[$ muhem $]$} & LM & elicitation & researcher \\
\hline 2 & {$[$ muhem $]$} & UB & staged conversation & LM \\
\hline 3 & {$[$ muhem $]$} & GS & staged conversation & LM, UB \\
\hline 4 & {$[$ mal $]$} & JT & elicitation & researcher \\
\hline
\end{tabular}


Lüpke, Friederike \& Rachel Watson. Forthcoming. Language contact in West Africa. In: Adamou, Evangelia \& Yaron Matras (eds.): The Routledge handbook of language contact.

\begin{tabular}{|l|l|l|l|l|}
\hline 5 & {$[$ muhem $]$} & GS & elicitation & researcher \\
\hline$\cdots$ & & & & \\
\hline $\mathrm{n}$ & {$[\mathrm{mal}]$} & GS & staged conversation & JT, UB \\
\hline
\end{tabular}

An aggregation of these results shows that there is a general consensus for the form [muhem]. This is the prototypical realisation of this form in Joola Kujieray. We also come across alternative forms. These are not discarded but rather can be quantitatively and qualitatively analysed, with the help of the rich sociolinguistic data which is an integral part of the descriptive methodology under this approach. Any form can be cross-referenced with data about the speaker's linguistic repertoire or the circumstances of the conversation. We may find that, for example, JT's deviation from the prototype is due to the prominence of Joola Banjal in his repertoire, where [mal] is prototypical. We can discover whether GS's deviation from the prototype in token (n) is to do with influence from his own repertoire, or that of his interlocutors, while in the more controlled context of elicitation, he successfully accesses the prototypical form. This approach enables the detailed observation of variation to investigate the dichotomy between languages as imaginary reifications and actual language use. Furthermore, variation can be motivated according to repertoires and contexts, providing a more nuanced view of contact effects. Once comparable databases are built up for languages across a contact area, this allows researchers to interpret thickly multilingual data of the type in example (1) below more meaningfully. They can also be used to carry out frequency searches to discover in which circumstances different variants occur, where borrowings and codeswitching are likely to occur, and investigate emerging contact effects (see Adamou (2016) and Cacoullos and Travis (2018). Furthermore, these analyses can then feed back into the prototype description in a virtuous research cycle.

\subsection{Identifying and analysing convergence and divergence in multilingual discourse.}

We have seen above that complex patterns of convergence and divergence are found in multilingual language ecologies, that languages can be conceived as collections of features and that social difference can be indexed through large and small linguistic differences. In the following we present a short piece of discourse that illustrates how speakers use their linguistic repertories in a fluid way, and discuss the implications that data of this sort has for an understanding of contact in such settings.

The extract is taken from a conversation between five men, in the village of Brin, Lower Casamance. The following conventions are used in the notation: Joola Kasa is in bold; material common to more than one Joola language, including Kasa, is in plain italics; material common to more than one Joola language, excluding Kasa, is in underlined italics. 
Lüpke, Friederike \& Rachel Watson. Forthcoming. Language contact in West Africa. In: Adamou, Evangelia \& Yaron Matras (eds.): The Routledge handbook of language contact.

Example 1: Conversation at the seminary

PB nu-has-om

2S-know-1S

'Do you know me?'

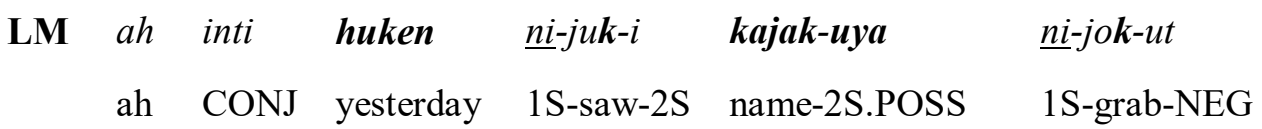

'Ah yesterday I saw you, it's your name that escapes me'

LM kajak-oli buu?

name-2S.POSS how

'What's your name?'

PB: kajaw-om pier pier betray

Name-1S.POSS Pierre Pierre Bertrand

'My name's Pierre, Pierre Bertrand'

The extract was transcribed by LM, a local, multilingual resident, who also happens to be one of the participants in the conversation. He segmented the discourse and tagged each segment for language. Nearly every segment was tagged as Joola Kasa, a Joola language patrimonial to a group of villages in the southern zone, and with relatively extensive reach as a language of wider communication, with some French, and some mixed French-Joola Kasa segments. Kasa itself is an intermediate level category integrating more locally confined subvarieties, and in this case, the categorisation is based on an outsider's view and an overarching linguistic identity commonly presented to outsiders. In subsequent discussion, LM confirmed that the conversation had taken place in Joola Kasa, and that the reason for this choice of Kasa among several shared languages was that the majority of the men present counted Joola Kasa as their most prominent vernacular language, including an important shrine holder with high social status. LM and PB were the only participants for whom Joola Kasa does not play a highly vernacular role, but for reasons of communicative expedience and respect, they aligned their language to their interlocutors.

However, from the perspective of the descriptive linguist, a different picture appears with respect to the prototypicality of the features in the discourse. First, much of the material is common to more than one Joola language, including Kasa (plain italics). There are indeed some features that can be identified as prototypically Joola Kasa (bold). Notably, however, given the transcriber's judgement, 
Lüpke, Friederike \& Rachel Watson. Forthcoming. Language contact in West Africa. In: Adamou, Evangelia \& Yaron Matras (eds.): The Routledge handbook of language contact.

there are several features that are not prototypical of Joola Kasa, but of other Joola languages (underlined italics). These latter features are ambiguous if looked at from a purely structural perspective, as they are found in several different Joola languages, including Joola Kujireray, Joola Banjal and Joola Fogny.

In order to interpret the data meaningfully we need to examine the intersection between the speakers' and analysts' perspectives. It was LM and PB's pragmatic intention to align with their interlocutors and speak Kasa, and they achieved this by using features they knew to be prototypically Kasa. However, since they do not have full access to the conventionalised forms of this language (it plays a more vehicular role in their repertoires) there is necessarily a process of bricolage, making do and filling in the gaps with material from other languages in their repertoire - such a process is recognised by speakers. It also follows, therefore, that an examination of LM and PB's repertoires may help to disambiguate the source of the 'rogue' features in the discourse. While the data in the preceding examples above are based on many years of fieldwork, participant observation, continued discussion with numerous speakers and language experts, the presentation of features as prototypical is still heuristic. Furthermore, the features discussed are some of the more prominent and agreed upon in the respective languages; a meaningful examination of features that are the subject of variation and disagreement requires a more thorough methodology, as described in 4.1. Scholarly works consulted in the analysis include Sapir (1965), Sambou (1979), Bassène (2007) and Sagna (2008).

This exchange is typical in its complexity, but unique, as is every interaction, in its particular constellation of speakers, repertoires and social and communicative requirements. Such intense mixing often makes it difficult to establish which language(s) are psycholinguistically dominant in discourse (van Coetsem, 2000; Winford, 2007). We therefore need to ask to what extent the heterogeneity of multilingual interaction precludes and/or shapes the sedimentation of contact effects (see Watson 2018).

Where contact effects are observed, they are rarely uniform or unidirectional, reflecting the multiplex, constantly shifting relationships between populations (McMahon et al., 2005). Borrowing from one language to another can be affected by factors including geographical proximity, political dominance relations between communities, and traditions of marriage exchange or agricultural cooperation, all of which can have opposed effects simultaneously as well as changing over time. This results in different strata of convergence and divergence, which can be analysed in a fine-grained, qualitative fashion with attention paid to semantic domains as well as socio-historical context.

For example, in Casamance it is overall far more common for Joola forms to be borrowed into Baïnounk languages than vice versa, due to the recent dominance of Joola populations in the region (Pozdniakov and Segerer, forthcoming (2019)). However, Watson (2018) shows that in one particular situation the reverse pattern is observed. The lexicon of Joola Kujireray contains a surprisingly high proportion of items apparently of Baïnounk origin, suggesting an asymmetric dominance relation in 
Lüpke, Friederike \& Rachel Watson. Forthcoming. Language contact in West Africa. In: Adamou, Evangelia \& Yaron Matras (eds.): The Routledge handbook of language contact.

the favour of Baïnounk, contrary to the prevailing pattern in Casamance. This corroborates oral history accounts of Brin as a new settlement, possibly even a captive settlement which eventually integrated with the surrounding Baïnounk populations. Conversely, it is shown that Joola Kujireray and Joola Banjal which are closely related and spoken in close geographical proximity, maintain quite different forms for basic and common vocabulary items such as 'water', 'sleep', 'cook', 'name' and 'fan palm'. It is posited that the maintenance of small but prominent differences, such as these frequent lexical items, as well as the phonetic differences described above, allows speakers to index their respective identities. Lüpke (forthcoming b) discusses a number of morphosyntatic patterns in Casamance languages and their areal spread and shows that their diffusion cannot be interpreted without a knowledge of the micro-history of settlement and migration. Mc Laughlin (1997) reveals different historical layers of borrowing and how they have reshaped the noun class system of Wolof, whose linguistic history is relatively well known. Yet, while it is straightforward to identify convergences, it is often impossible to determine their exact origin, except in a deep etymological sense, as also evident in Vydrine's (1999) overview of lexical similarities between Mandinka and Joola Fogny. Additionally, it is not always clear whether a construction that etymologically belongs to a particular language reached another language via direct transfer or was diffused areally. 'Wanderwörter' such as caabi 'key', ultimately from Portuguese or Kriol, are attested over wide areas, as are semantic calques such as nightly avoidance terms for 'salt', 'charcoal', 'needle' and 'snake' (Luffin, 2002; Minkailou, 2016; Biagui, Nunez and Quint, forthcoming (2019);).

Newer approaches to language contact and multilingualism are therefore agnostic to motivation (genealogical relatedness vs. language contact) and directionality of convergences but flag forms that share features of several named codes as exhibiting features of all of them (Nunez and Léglise, 2016). However, the perspectives of users and analysts in categorising constructions as 'belonging' to one or several reified codes are not always identical as we have seen in example 1 above, since speakers', hearers' and analysts' repertoires and the associated with codes in them constrain their base of comparison. Goodchild and Weidl (2018), Goodchild (2019), Weidl (2019) and Lüpke (forthcoming a) therefore build perspective into the analytical process by instrumentalising rather than resolving difference in categorisation. Figure 4 illustrates different perspectives on the categorisation of the lexical item grawul 'it's not a problem', often analysed as a mixed form combining a French stem and a Wolof suffix, based on the speaker's repertoire: 
Lüpke, Friederike \& Rachel Watson. Forthcoming. Language contact in West Africa. In: Adamou, Evangelia \& Yaron Matras (eds.): The Routledge handbook of language contact.

Figure 3 Influence of perspective on linguistic categorisation

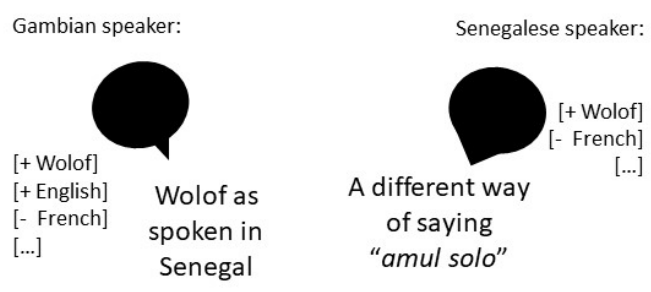

\section{< grawul >}

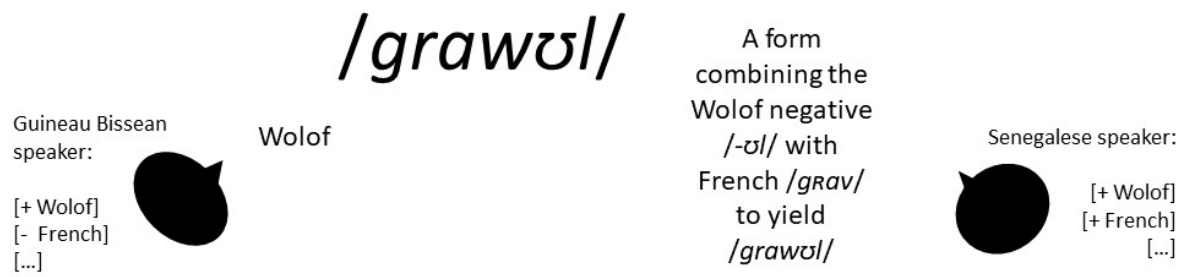

The inclusion of perspective is not only crucial for an understanding of speakers' possibilities and intentions and hearers' possible interpretations; it is also indispensable for an analysis of multilingual speech and traces of language contact in it, particularly in the case of closely related lects reified as different socially meaningful entities but characterised by huge areas of feature overlap or ambiguity in lexico-grammatical terms.

\section{Main research methods and future directions}

Long driven by individual research, newer multilingualism and contact studies in West Africa are taking a collaborative and multidisciplinary turn. Such larger initiatives are required because of the complexity of settings, both in terms of size of repertoires and number of named languages, and in terms of the state of linguistic description, which is dire for most West African languages. Despite persistent and systemic challenges in terms of access to funding and intercontinental mobility and exchange for researchers based in Africa, there is a tendency for greater collaboration with West African researchers and a greater involvement of research participants in the research design, transcription and analysis. A number of disciplinary perspectives that have not been joined in the past are combined, most notably in the complementation of descriptive and documentary approaches with sociolinguistic and anthropological linguistic viewpoints (Childs, Good and Mitchell, 2014; Meyerhoff and Stanford, 2015). The focus of many sociolinguistic investigations has been on urban settings, while language description and documentation, adopting a language-based outlook, tended to concentrate on rural settings. Language contact studies concentrated on language pairs exhibiting 
Lüpke, Friederike \& Rachel Watson. Forthcoming. Language contact in West Africa. In: Adamou, Evangelia \& Yaron Matras (eds.): The Routledge handbook of language contact.

great genetic and typological contrasts, thereby sidestepping issues of variation and contact on a smaller scale and an investigation of settings in their full complexity. That focus is now shifting, and rural configurations and more multifaceted aspects of multilingualism are receiving more attention. New methods are being developed to create optimal workflows enabling international and interdisciplinary teams to transcribe, annotate, and share data (Watson, in preparation, 2017), to analyse multilingual corpora (Léglise and Alby, 2016), and to visualise socio-spatial patterns of multilingualism (in an on-going project at the University at Buffalo).

Studies on language socialisation and acquisition in West Africa's multilingual settings remain rare but receive growing attention (Moore, 2008; Cissé, 2013, forthcoming (2019)). Psycholinguistic studies with bi- or multilingual West African speakers are non-existent, apart from a pioneering study of gesture- and speech alignment in multilingual speech in the Casamance region of Senegal (Krajcik, 2019). Findings in both areas challenge frameworks and findings of mainstream studies and thus have great potential to advance the understanding of language interaction in linguistic settings that are more representative for the evolution of language overall than the W.E.I.R.D - Western, educated, industrialised, rich, democratic - settings (Henrich, Heine and Norenzayan, 2010) that dominate language acquisition research and psycholinguistics.

Multimodality - the co-existence and interaction of speech with other linguistic modalities including gesture, sign language and writing - emerges as another domain of great relevance to better capture the multidimensional nature of language use in West Africa and firmly establishes it as an area of investigation that can advance fields such as language planning and sign language research. Regarding the former, multilingualism management in West Africa, through the ways in which communities have structured written communication in heteroglossic and multilingual communities and have created ways for lifelong informal language learning, is an important area for contact research that also has much inspiration to offer to multilingualism management and education (Souag, 2010; Lüpke et al., accepted (2018); Lüpke, forthcoming c). Concerning sign language research, the existence of village-sign language communities consisting of Deaf signers and a large proportion of their hearing co-inhabitants (Nyst, 2010) is of similar relevance for Deaf studies and Deaf education.

Finally, how West African and European multilingualism and contact patterns are transformed through migration at the national and international scale (Juffermans and Tavares, 2017) and what its impact is on the maintenance and adaptation of multilingual repertoires, including their locally confined parts, is an important research area that can provide urgent insights for research on language endangerment and language vitality. West Africa's resilient multilingualism, despite the availability of languages of wider communication since the onset of early globalisation, is remarkable and illustrates that language contact, change and shift do not operate uniformly but based on social functions of language in locally meaningful settings (Di Carlo and Good, 2017; Lüpke, 2017; 
Lüpke, Friederike \& Rachel Watson. Forthcoming. Language contact in West Africa. In: Adamou, Evangelia \& Yaron Matras (eds.): The Routledge handbook of language contact.

Mufwene, 2017). Investigations of these settings are timely because insight into different patterns and planes of language contact and multilingualism in (West) Africa can transform epistemological frames and methods to free empirical research from a priori theorisations inapplicable to its ecologies.

\section{Further Reading}

Beyer, Klaus; Schreiber, Henning (2017): Social network approach in African sociolinguistics. In Oxford Research Enclopedias. DOI: 10.1093/acrefore/9780199384655.013.236.

Focusing on West Africa, where most of this research (by the authors) has been conducted, this article gives insight in methods and analyses of social network studies, linking the spread of linguistic features in multilingual populations to social interaction.

Good, Jeff; Di Carlo, Pierpaolo; Ojong, Rachel (2019): Multilingualism in rural Africa. In Oxford Research Enclopedias. DOI: 10.1093/acrefore/9780199384655.013.227.

This article provides the first systematic overview of underresearched multilngualism in rural areas of Africa.

Juffermans, Kasper; Abdelhay, Ashraf (2016): Literacy and multilingualism in Africa. In Brian V. Street, Stepen May (Eds.): Literacies and language education. Encycopleadia of language and education. Berlin/Bonn: Springer, checked on 12/11/2017.

This work presents a synthesis of research on written multilingualism and language contact on the African continent.

Lüpke, Friederike (forthcoming): Language contact in West Africa. In Oxford Research Enclopedias.

This article offers an extended overview on the Atlantic and Mande spaces of West Africa, including a detailed historical account, as well as on epistemological and methodological issues.

Lüpke, Friederike; Chambers, Mary (Eds.) (2010): Multilingualism and language contact in West Africa: towards a holistic perspective: Journal of Language Contact THEMA 3.

This special issue offers a number of case studies on multilingualism and language contact in West Africa.

\section{Related topics}

Pidgin and Creoles, Sahara, social factors; the benefits and challenges of multilingual corpora, usagebased approaches

\section{References}

Adamou, E. (2016) A Corpus-driven approach to language contact: endangered languages in a comparative perspective. Boston: Dawsons; De Gruyter Mouton.

Agha, A. (2005) 'Voice, footing, enregisterment', Journal of Linguistic Anthropology, 15, pp. 38-59. 
Lüpke, Friederike \& Rachel Watson. Forthcoming. Language contact in West Africa. In: Adamou, Evangelia \& Yaron Matras (eds.): The Routledge handbook of language contact.

Amselle, J.-L. (1990) Logiques métisses. Anthropologie de l'identité en Afrique et ailleurs. Paris: Payot.

Amselle, J.-L. and M'Bokolo, E. (eds.) (1985) Au cour de l'ethnie: ethnies, tribalisme et état en Afrique. Paris: La Découverte/Poche.

Auzeanneau, M., Bento, M. and Leclère, M. (2016) 'Introduction: Étude des pratiques plurilingues et défis contemporains. Hommage à Caroline Juillard, Professeure', in Auzeanneau, M., Bento, M. and Leclère, M. (eds.) Pratiques plurilingues, mobilités et éducation: Éclairages d'Afrique ou d'ailleurs. Paris: Édition des Archives Contemporaines, pp. i-viii.

Barry, A. (1990) 'Étude du plurilinguisme au Mali:: le cas de Djenné', in Kawada, J. (ed.) Boucle du Niger: Approches multidisciplinaires (2 vols). Tokyo, pp. 183-207.

Bassène, A.-C. (2007) Morphosyntaxe du joola banjal. Langue atlantique du Senegal. Köln: Rüdiger Köppe.

Bazin, J. (1985) 'À chacun son bambara', in Amselle, J.-L. and M'Bokolo, E. (eds.) Au cour de l'ethnie: ethnies, tribalisme et état en Afrique. Paris: La Découverte/Poche, pp. 87-125.

Bentz, C. et al. (2018) 'The evolution of language families is shaped by the environment beyond neutral drift', Nature Human Behaviour, 2(11), pp. 816-821.

Beyer, K. (2010) 'Language contact and change: a look at social factors in an African rural environment', in Lüpke, F. and Chambers, M. (eds.) Multilingualism and language contact in West Africa: towards a holistic perspective: Journal of Language Contact THEMA 3, pp. 131-152.

Beyer, K. and Schreiber, H. (2013) 'Intermingling speech groups: morphosyntactic outcomes of language contact in a linguistic area in Burkina Faso (West Africa)', in Leglise, I. and Chamoreau, C. (eds.) The interplay of variation and change in contact settings morphosyntactic studies. Amsterdam/Philadelphia: John Benjamins.

Biagui, N.B., Nunez, J.J.-F. and Quint, N. (forthcoming (2019)) 'Casamance Creole', in Lüpke, F. (ed.) The Oxford guide to the Atlantic languages of West Africa. Oxford: Oxford University Press.

Blommaert, J. (2010) The sociolinguistics of globalization. Cambridge: Cambridge University Press.

Blommaert, J. and Rampton, B. (2012) 'Language and superdiversity', MMG Working Paper, 12(9).

Boutin, B.A.B. and N'Guessan, J.K. (2015) 'Le nouchi c'est notre créole en quelque sorte, qui est parlé par presque toute la Côte d'Ivoire', in Blumenthal, P. (ed.) Peter Blumenthal. Dynamique des français africains : entre le culturel et le linguistique. Frankfurt: Peter Lang.

Brooks, G.E. (1993) Landlords and strangers: ecology, society, and trade in Western Africa, 1000-1630. (African states and societies in history). Boulder CO/Oxford: Westview Press.

Busch, B. (2006) 'Language biographies: Approaches to multilingualism in education and linguistic research', PRAESA Occasional Papers, pp. 5-18. 
Lüpke, Friederike \& Rachel Watson. Forthcoming. Language contact in West Africa. In: Adamou, Evangelia \& Yaron Matras (eds.): The Routledge handbook of language contact.

Cacoullos, R.T. and Travis, C.E. (2018) Bilingualism in the community. Cambridge: Cambridge University Press.

Calvet, L.-J. (1993) Les langues des marchés en Afrique. (Langues et développement). Aixen-Provence: Inst. d'Études Créoles et Francophones.

Canós-Donnay, S. (2019) 'The Empire of Mali', Oxford Research Enclopedias. doi: 10.1093/acrefore/9780190277734.013.266

Canut, C. (2010) 'De l'Afrique des langues à l'Afrique des discours. Les voix du langagiaire', Cahiers d'Études Africaines, 198-199-20(2-3-4), pp. 1163-1189.

Chaudenson, R. and Calvet, L.J. (2001) 'Les langues dans l'espace francophone: De la coexistence au partenariat', Langues et développement.

Cheshire, J. et al. (2011) 'Contact, the feature pool and the speech community: the emergence of Multicultural London English', Journal of Sociolinguistics, 15(2), pp. 151-196.

Chia, E. (1990) 'The new speech forms of rapidly growing city: Pidgin French and Camfranglais in Yaounde', Annales de la Faculté des Lettres et Sciences Humaines, Université de Yaoundé, 6, pp. 102-127.

Childs, G.T. (forthcoming (2019)) 'Genetic clusters in Atlantic', in Lüpke, F. (ed.) The Oxford guide to the Atlantic languages of West Africa. Oxford: Oxford University Press.

Childs, G.T., Good, J. and Mitchell, A. (2014) 'Beyond the ancestral code: Towards a model for sociolinguistic language documentation', Language Documentation and Conservation, 8, 168-191.

Cissé, I. (2013) Emergence of linguistic systems in interaction: development of phonological and morpho-phonological skills in bilingual children (Bambara-Fulfulde), compared with monolingual children Fulfulde/Bambara.

Cissé, I. (forthcoming (2019)) 'Multilingual children's language socialization in central Mali', in Lüpke, F. (ed.) The Oxford guide to the Atlantic languages of West Africa. Oxford: Oxford University Press.

Clements, G.N. and Rialland, A. (2008) 'Africa as a phonological area', in Heine, B. and Nurse, D. (eds.) A linguistic geography of Africa. Cambridge: Cambridge University Pres, pp. 36-85.

Cobbinah, A. (2010) 'The Casamance as an area of intense language contact: The case of Baïnouk Gubaher', in Lüpke, F. and Chambers, M. (eds.) Multilingualism and language contact in West Africa: towards a holistic perspective: Journal of Language Contact THEMA 3, pp. 175-201.

Cobbinah, A. et al. (2016) 'Carrefour des langues, carrefour des paradigmes', in Auzeanneau, M., Bento, M. and Leclère, M. (eds.) Pratiques plurilingues, mobilités et éducation: Éclairages d'Afrique ou d'ailleurs. Paris: Édition des Archives Contemporaines, 79-96.

Cobbinah, A.Y. (forthcoming) 'An ecological approach to ethnic identity and language dynamics in a multilingual area (Lower Casamance, Senegal)', in Good, J. and Di Carlo, P. (eds.) African MultilingualismS. Selected proceedings from the International Conference, Yaounde 12 August 2017. Lanham MD: Lexington Books. 
Lüpke, Friederike \& Rachel Watson. Forthcoming. Language contact in West Africa. In: Adamou, Evangelia \& Yaron Matras (eds.): The Routledge handbook of language contact.

Coquery-Vidrovitch, C. (2005) The history of African cities south of the Sahara. Princeton: Wiener.

Cruise O'Brien, D. (1998) 'The shadow-politics of Wolofisation', The Journal of Modern African Studies, 36(1), pp. 25-46.

Dalby, D. (1970) 'Reflections on the classification of African languages: With special reference to the work of Sigismund Wilhelm Koelle and Malcolm Guthrie', African Language Studies, 11, pp. 147-171.

Di Carlo, P. (2016) 'Multilingualism, affiliation, and spiritual insecurity: From phenomena to processes in language documentation', Language Documentation and Conservation, pp. 71104.

Di Carlo, P. (2018) 'Towards an understanding of African endogenous multilingualism: Ethnography, language ideologies, and the supernatural', International Journal of the Sociology of Language, 2018(254), pp. 139-163.

Di Carlo, P., Agwara, A.D.E. and Ojong, R.A. (forthcoming) 'Multilingualism and the heteroglossia of ideologies in Lower Fungom (Cameroon)', Sociolinguistic Studies.

Di Carlo, P. and Good, J. (2014) 'What are we trying to preserve? Diversity, change and ideology at the edge of the Cameroonian Grassfields', in Austin, P.K. and Sallabank, J. (eds.) Endangered Languages: Beliefs and Ideologies in Language Documentation and Revitalization. Oxford: Oxford University Press and The British Academy, pp. 231-262.

Di Carlo, P. and Good, J. (2017) 'The vitality and diversity of multilingual repertoires: Commentary on Mufwene', Language, 93(4), e254-e262.

Diamond, J.M. (1999) Guns, germs, and steel: the fates of human societies. New YorkLondon: W.W. Norton.

Dimmendaal, G.J. and Storch, A. (2016) 'Niger-Congo: a brief state of the art: Oxford Handbooks Online'.

Donaldson, C. (2018) 'Orthography, standardization and register: The case of Manding', in Lane, P., Costa, J. and Korne, H. de (eds.) Standardizing mnority languages. New York and London: Routledge, pp. 175-199.

Dreyfus, M. and Juillard, C. (2004) Le plurilinguisme au Sénégal: Langues et identités en devenir. Paris: Karthala.

Eckert, P. (2008) 'Variation and the indexical field', Journal of Sociolinguistics, 12(4), pp. $453-476$.

Faraclas, N. (2013) 'Nigerian Pidgin', in Michaelis, S.M. et al. (eds.) The survey of pidgin and creole languages. Oxford: Oxford University Press.

Fardon, R. and Furniss, G. (eds.) (1994) African languages, development and the state. London: Routledge.

Finney, M.A. (2013) 'Krio', in Michaelis, S.M. et al. (eds.) The survey of pidgin and creole languages. Oxford: Oxford University Press.

Fishman, J.A. (1989) Language and ethnicity in minority sociolinguistic perspective. Bristol: Multilingual Matters. 
Lüpke, Friederike \& Rachel Watson. Forthcoming. Language contact in West Africa. In: Adamou, Evangelia \& Yaron Matras (eds.): The Routledge handbook of language contact.

François, A. (2014) 'Trees, waves and linkages: models of language diversification', in Bowern, C. (ed.) The Routledge handbook of historical linguistics: Routledge, pp. 161-189.

François, A. (2017) 'Méthode comparative et chaînages linguistiques : Pour un modèle diffusionniste en généalogie des langues', in Léonard, J.-L. (ed.) Diffusion : implantation, affinités, convergence. (Mémoires de la Société de Linguistique de Paris, XXIV): Peeters, pp. 43-82.

Gafaranga, J. and Torras, M.-C. (2016) 'Interactional otherness: Towards a redefinition of codeswitching', International Journal of Bilingualism, 6(1), pp. 1-22.

Gal, S. (2016) 'Scale-making: comparison and perspective as ideological projects', in Carr, E.S. and Lempert, M. (eds.) Scale: Discourse and dimensions of social life. (OAPEN Library). Oakland, California: University of California Press, pp. 91-111.

Good, J. (2013) 'A (micro-)accretion zone in a remnant zone? Lower Fungom in arealhistorical perspective', in Bickel, B. et al. (eds.) Language typology and historical contingency: In honor of Johanna Nichols. (Typological studies in language, 0167-7373, volume 104). Amsterdam/Philadelphia: John Benjamins, pp. 265-282.

Good, J., Di Carlo, P. and Ojong, R. (2019) 'Multilingualism in rural Africa', Oxford Research Enclopedias.

Goodchild, S. (2016) "Which language(s) are you for?" "I am for all the languages.": Reflections on breaking through the ancestral code: trials of sociolinguistic documentation', SOAS Working Papers in Linguistics, 18, pp. 75-91.

Goodchild, S. (2019) Sociolinguistic spaces and multilingual repertoires: practices and perceptions in Essyl, Senegal. PhD thesis. SOAS.

Goodchild, S. and Weidl, M. (2018) 'Translanguaging practices in the Casamance: similar but different - two case studies', in Sherris, A. and Adami, E. (eds.) Making signs, translanguaging ethnographies: Exploring urban, rural and educational spaces. Bristol: Multilingual Matters, pp. 133-151.

Goodchild, S. (forthcoming (2019)) 'Multilingual people with monolingual perceptions: patterns of multilingualism in Essyl, Basse Casamance, Senegal', in Lüpke, F. (ed.) The Oxford guide to the Atlantic languages of West Africa. Oxford: Oxford University Press.

Green, D.W. (2011) 'Language control in different contexts: the behavioral ecology of bilingual speakers', Frontiers in Psychology, 2(103), pp. 2-4.

Green, D.W. and Abutalebi, J. (2013) 'Language control in bilinguals: The adaptive control hypothesis', Journal of Cognitive Psychology, 25(5), pp. 515-530.

Güldemann, T. (2008) 'The Macro-Sudan belt: towards identifying a linguistic area in northern sub-Saharan Africa', in Heine, B. and Nurse, D. (eds.) A linguistic geography of Africa. Cambridge: Cambridge University Press, pp. 151-185.

Güldemann, T. (2010) 'Sprachraum and geography: linguistic macro-areas in Africa', in Lameli, A., Kehrein, R. and Rabanus, S. (eds.) Language and space: Volume 2, Language mapping. Berlin: De Gruyter Mouton, pp. 561-593.

Güldemann, T. and Hammarström, H. (forthcoming) 'Geographical axis effects in large-scale linguistic distributions’, in Muysken, P., Crevels, M. and Hombert, J.-M. (eds.) Language 
Lüpke, Friederike \& Rachel Watson. Forthcoming. Language contact in West Africa. In: Adamou, Evangelia \& Yaron Matras (eds.): The Routledge handbook of language contact.

dispersal, diversification, and contact. A global perspective. Oxford: Oxford University Press.

Gut, U. (2015) 'English in West Africa', in Filppula, M., Klemola, J. and Sharma, D. (eds.). The Oxford handbook of world Englishes. Oxford: Oxford University Press.

Hantgan, A. (2017) 'Choices in language accommodation at the Crossroads: convergence, divergence, and mixing', Journal of the Anthropological Society of Oxford Online, 9(1), pp. 102-118.

Henrich, J., Heine, S.J. and Norenzayan, A. (2010) 'The weirdest people in the world?' Behavioral and Brain Sciences, 33(2-3), 61-83; discussion 83-135.

Intumbo, I., Inverno, L. and Holm, J. (2013) 'Guinea-Bissau Kriyol', in Michaelis, S.M. et al. (eds.) The survey of pidgin and creole languages. Oxford: Oxford University Press.

Irvine, J.T. (2016) 'Going upscale: scales and scale-climbing as ideological projects', in Carr, E.S. and Lempert, M. (eds.) Scale: Discourse and dimensions of social life. (OAPEN Library). Oakland, California: University of California Press, pp. 213-231.

Jacobs, B. (2010) 'Upper Guinea Creole: Evidence in favor of a Santiago birth', Journal of Pidgin and Creole Languages, 25(2), pp. 289-343.

Jørgensen, J.N. et al. (2011) 'Polylanguaging in superdiversity', Diversities, 13(2).

Juffermans, K. and Tavares, B. (2017) 'South-North trajectories and language repertoires', in Kerfoot, C. and Hyltenstam, K. (eds.) Entangled discourses: South-North orders of visibility. London: Taylor \& Francis, pp. 99-115.

Juillard, C. (1995) Sociolinguistique urbaine. La vie des langues à Ziguinchor (Sénégal). Paris: Presses du CNRS.

Kießling, R. (2005) '”bak mwa me do'-Camfranglais in Cameroon', Lingua Posnaniensis, 47, pp. 87-107.

Kopytoff, I. (1987) 'The internal African frontier: the making of African political culture', in Kopytoff, I. (ed.) The African frontier: The reproduction of traditional African society. Bloomington: Indiana University Press, pp. 3-84.

Krajcik, C. (2019) Exploring multilingualism in Senegal: a multimodal approach to the expression of caused motion. $\mathrm{PhD}$ thesis. SOAS, University of London.

Léglise, I. and Alby, S. (2016) 'Plurilingual corpora and polylanguaging, where corpus linguistics meets contact linguistics', Sociolinguistic Studies, 10(3), pp. 357-381.

Lentz, C. (1995) 'Tribalism' and ethnicity in Africa', Cahiers des Sciences Humaines, 31(2), pp. 303-328.

Lentz, C. (2013) Land, mobility, and belonging in West Africa. Bloomington, Indiana: Indiana University Press.

Lexander, K.V. (2010) 'Voeux plurilingues électroniques - nouvelles pratiques, nouvelles fonctions pour les langues africaines ?' Journal of Language Contact, THEMA 3, pp. 205228.

Lexander, K.V. and Alcón, D. (forthcoming (2019)) 'Digital language and new configurations of multilingualism: language use in a Senegal-based discussion forum', in 
Lüpke, Friederike \& Rachel Watson. Forthcoming. Language contact in West Africa. In: Adamou, Evangelia \& Yaron Matras (eds.): The Routledge handbook of language contact.

Lüpke, F. (ed.) The Oxford guide to the Atlantic languages of West Africa. Oxford: Oxford University Press.

Luffin, X. (2002) 'Language taboos in Kinubi: a comparison with Sudanese and Swahili cultures', Africa: Rivista trimestrale di studi e documentazione dell'Istituto italiano perl'Africa e l'Oriente, 57(3), pp. 356-367.

Lüpke, F. (2010) 'Language and identity in flux: in search of Baïnouk', in Lüpke, F. and Chambers, M. (eds.) Multilingualism and language contact in West Africa: towards a holistic perspective: Journal of Language Contact THEMA 3, pp. 155-174.

Lüpke, F. (2016a) 'Pure fiction - the interplay of indexical and essentialist ideologies and heterogeneous practices: A view from Agnack.', Language Documentation and Conservation, Special Publication 10, pp. 8-39.

Lüpke, F. (2016b) 'Uncovering small-scale multilingualism', Critical Multilingualism Studies, 4(2), pp. 35-74.

Lüpke, F. (2017) 'African(ist) perspectives on vitality: Fluidity, small speaker numbers, and adaptive multilingualism make vibrant ecologies (Response to Mufwene)', Language, 93(4), e275-e279. doi: 10.1353/lan.2017.0071

Lüpke, F. (2018) 'Multiple choice: language use and cultural practice in rural Casamance between convergence and divergence', in Knörr, J. and Filho, W.T. (eds.) Creolization and pidginization in contexts of postcolonial diversity: language, culture, identity. Leiden: Brill, pp. 181-208.

Lüpke, F. and Chambers, M. (eds.) (2010) Multilingualism and language contact in West Africa: towards a holistic perspective: Journal of Language Contact THEMA 3 (Accessed: 21 February 2014).

Lüpke, F. et al. (accepted (2018)) 'LILIEMA: Language-independent literacies for inclusive education in multilingual areas', Language and Development Series of the British Council.

Lüpke, F. et al. (under revision (2019)) 'Comparing rural multilingualism in Lowland South America and Western Africa', Anthropological Linguistics.

Lüpke, F. (forthcoming a) 'Language contact in West Africa: From objects of enquiry to new ways of thinking and linking language and languaging', in Aronoff, M. (ed.) Oxford Research Encyclopedia in Linguistics. Oxford: Oxford University Press.

Lüpke, F. (forthcoming b) 'Language contact in West Africa', Oxford Research Enclopedias.

Lüpke, F. (forthcoming c) 'Standardization in highly multilingual contexts: the shifting interpretations, limited reach, and great symbolic power of ethnonationalist visions', in Ayres-Bennett, W. and Bellamy, J. (eds.) The Cambridge handbook of standard languages. Cambridge.

Manessy, G. (1994) Les français en Afrique noire: Mythe, stratégies, pratiques. Paris: L'Harmattan.

Marten, L. and Petzell, M. (2016) 'Linguistic variation and the dynamics of language documentation: Editing in 'pure' Kagulu', Language Documentation and Conservation, Special Publicatin 10, pp. 105-129. 
Lüpke, Friederike \& Rachel Watson. Forthcoming. Language contact in West Africa. In: Adamou, Evangelia \& Yaron Matras (eds.): The Routledge handbook of language contact.

Matras, Y. (2009) Language contact. Cambridge: Cambridge University Press.

Matras, Y. (2012) 'An activity-oriented approach to contact-induced language change', in Chamoreau, C. and Léglise, I. (eds.) Dynamics of contact-induced language change.

(Language contact and bilingualism, 2). Berlin: De Gruyter Mouton, pp. 1-28.

Mc Laughlin, F. (1997) 'Noun classification in Wolof - when affixes are not renewed', Studies in African linguistics, 26(1), pp. 1-28.

Mc Laughlin, F. (2001) 'Dakar Wolof and the configuration of an urban identity', Journal of African Cultural Studies, 14(2), pp. 153-172.

Mc Laughlin, F. (2008) 'On the origins of Urban Wolof: Evidence from Louis Descemet's 1864 phrase book', Language in Society, 37(5), pp. 713-735.

Mc Laughlin, F. (2014) 'Senegalese digital repertoires in superdiversity: A case study from Seneweb', Discourse, Context and Media, 4(4), pp. 29-37.

McMahon, A. et al. (2005) 'Swadesh Sublists and the benefits of borrowing: An Andean case study', Transactions of the Philological Society, 103(2), pp. 147-170.

Meyerhoff, M. and Stanford, J.N. (2015) "'Tings change, all tings change": the changing face of sociolinguistics with a global perspective', in Smakman, D. and Heinrich, P. (eds.)

Globalising sociolinguistics: Challenging and expanding theory. London: Routledge Taylor \& Francis Group, pp. 1-15.

Milroy, L. (1980) Language and social networks. (Language in society (Oxford), 2). Oxford: Blackwell.

Minkailou, M. (2016) 'Exploring euphemism in standard Songhay', Recherches Africaines. Annales de l'Université des Lettres et Sciences Humaines de Bamako, 16, pp. 31-39.

Moore, L.C. (2008) 'Body, text and talk in Maroua Fulbe Qur'anic schooling', Text \& Talk, 28(5), pp. 643-665.

Mufwene, S.S. (1996) 'The founder principle in creole genesis', Diachronica, 13(1), pp. 83134.

Mufwene, S.S. (2001) The ecology of language evolution. Cambridge: Cambridge University Press.

Mufwene, S.S. (2017) 'Language vitality: The weak theoretical underpinnings of what can be an exciting research area', Language, 93(4), e202-e223.

Myers-Scotton, C. (1993) Social motivations for codeswitching: evidence from Africa. Oxford: Oxford University Press..

Ndecky, A. (2011) Pratiques et répresentations des parlers mancanges de Goudomp (Sénégal). $\mathrm{PhD}$ thesis. Université de Picardie Jules Vernes.

Ngom, F. (2017) 'West African Manuscripts in Arabic and African Languages and Digital Preservation', Oxford Research Enclopedias. doi: 10.1093/acrefore/9780190277734.013.123

Nunez, J.-F. (2015) L'alternance entre créole afro-portugais de Casamance, français et wolof au Sénégal : une contribution trilingue à l'étude du contact de langues $» . \mathrm{PhD}$ thesis. INALCO. 
Lüpke, Friederike \& Rachel Watson. Forthcoming. Language contact in West Africa. In: Adamou, Evangelia \& Yaron Matras (eds.): The Routledge handbook of language contact.

Nunez, J.-F. and Léglise, I. (2016) 'Ce que les pratiques langagières plurilingues au Sénégal disent à la linguistique du contact', in Auzeanneau, M., Bento, M. and Leclère, M. (eds.) Pratiques plurilingues, mobilités et éducation: Éclairages d'Afrique ou d'ailleurs. Paris: Édition des Archives Contemporaines, pp. 99-119.

Nyst, V. (2010) 'Sign languages in West Africa', in Brentari, D. (ed.) Sign languages. Cambridge: Cambridge University Press, pp. 405-432.

Pozdniakov, K. (2007) 'Etudes atlantiques comparatives: questions de méthodologie', in Lemaréchal, A. (ed.) Tradition et rupture dans les grammaires comparées de différentes familles de langues. Leuven: Peeters, pp. 93-120.

Pozdniakov, K. and Segerer, G. (2010) Classification des langues atlantiques mise à jour. Ndayane.

Pozdniakov, K. and Segerer, G. (forthcoming (2019)) 'A genealogical classification of Atlantic languages', in Lüpke, F. (ed.) The Oxford guide to the Atlantic languages of West Africa. Oxford: Oxford University Press.

Ranger, T. (1983) 'The invention of tradition in colonial Africa', in Hobsbawm, E.J. and Ranger, T.O. (eds.) The invention of tradition. Cambridge: Cambridge University Press, pp. 211-262.

Rosch, E. (1975) 'Cognitive representations of semantic categories. In Journal of Experimental Psychology’, Journal of Experimental Psychology, General (104)(3), pp. 192233.

Rosch, E. and Mervis, C. (1975) 'Family resemblance: studies in the internal structure of categories', Cognitive Psychology, 7, pp. 573-605.

Sagna, S. (2008) Formal and semantic properties of the Gújjolaay Eegimaa nominal classficiation system. PhD. University of London.

Sagna, S. (forthcoming (2019)) 'A typological overview of Eegimaa (Jóola Banjal)', Studies in African linguistics.

Sambou, P.-M. (1979) Diola Kaasa Esuulaalur. Phonologie, Morphophonologie et Morphologie. UCAD Dakar.

Sapir, D.J. (1975) 'Big and thin: two Diola-Fogny meta-linguistic terms', Language in Society, 4(1), pp. 1-15.

Sapir, J.D. (1965) A grammar of Diola-Fogny. Cambridge: Cambridge University Pres.

Silverstein, M. (2003) 'Indexical order and the dialectics of sociolinguistic life', Language \& Communication, 23, pp. 193-229.

Smakman, D. and Heinrich, P. (eds.) (2015) Globalising sociolinguistics: Challenging and expanding theory. London: Routledge Taylor \& Francis Group.

Souag, L. (2010) 'Ajami in West Africa', Afrikanistik Online, 7, pp. 1-11. Available at: http://eprints.soas.ac.uk/13429/.

Swigart, L. (1994) 'Cultural creolisation and language use in post-colonial Africa: the case of Senegal’, Africa, 64(2), pp. 175-189. doi: 10.2307/1160978 
Lüpke, Friederike \& Rachel Watson. Forthcoming. Language contact in West Africa. In: Adamou, Evangelia \& Yaron Matras (eds.): The Routledge handbook of language contact.

Tamari, T. and Bondarev, D. (eds.) (2013) Qur'anic exegesis in African languages: Journal of Qur'anic Studies.

Trudgill, P. (2011) Sociolinguistic typology: Social determinants of linguistic complexity. Oxford: Oxford University Press.

van Coetsem, F. (2000) A general and unified theory of the transmission process in language contact. (Monographien zur Sprachwissenschaft, Bd. 19). Heidelberg: Winter.

Vydrine, V. (1999) 'Language contact: the case of Manding and Jola Fogny', Mande Studies, 1, pp. 141-157.

Watson, R. (2017) Data management workflow. Available at: http://soascrossroads.org/2017/ 05/ (Accessed: 13 February 2017).

Watson, R. (2018) 'Patterns of lexical correlation and divergence in Casamance', Language \& Communication, pp. 1-14.

Watson, R. (2019) 'Language as category: using prototype theory to create reference points for the study of multilingual data', Language and Cognition (11), pp. 125-164.

Watson, R. (in preparation) 'A distributed workflow for the creation, annotation, and archiving of multilingual data in collaborative, multisited documentation projects'.

Wei, L. (2018) 'Translanguaging as a Practical Theory of Language', Applied Linguistics, 39(1), pp. 9-30.

Weidl, M. (2019) Nga ne!? [What did you say!?]: The role of Wolof in multilingual conversations in the Casamance: fluidity of linguistic repertoires. $\mathrm{PhD}$ thesis. $\mathrm{SOAS}$.

Winford, D. (2007) 'Some issues in the study of language contact', Journal of Language Contact, THEMA 1.

Woodbury, A.C. (2005) 'Ancestral languages and (imagined) creolisation'. Language Documentation and Description 3, pp. 252-262. 